\title{
Influence of Cold Chain Integrity during Postwashing Processing and Storage on Chicken Egg Quality
}

\section{-Author(s)}

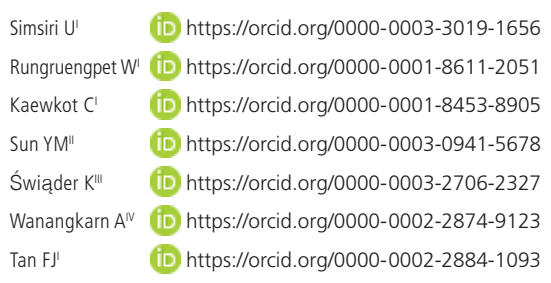

Department of Animal Science, National Chung Hsing University, Taichung, 402, Taiwan.

National Animal Industry Foundation, Taipei, 100, Taiwan.

III Faculty of Human Nutrition and Consumer Sciences, Warsaw University of Life Sciences SGGW, Warsaw, Poland.

Iv Department of Agricultural Science, Faculty of Agriculture, Natural Resources and Environment, Naresuan University, Phitsanuloke 65000, Thailand.

\section{ABSTRACT}

This study investigated the influence of cold chain integrity during postwashing processing and storage on chicken egg quality. Postwashed eggs from a commercial washing plant were assigned to eight groups that simulated the conditions of postwashing temporary storage, transportation, selling, and storage. At each step, eggs were stored at low $\left(7^{\circ} \mathrm{C}\right)$ or high $\left(25^{\circ} \mathrm{C}\right.$ or $\left.30^{\circ} \mathrm{C}\right)$ temperatures for a certain period of time to simulate commercial handling. Freshness and microbial characteristics of the eggs were analyzed for 4 weeks. The results demonstrated that eggs stored at low temperatures during all three steps in the cold chain maintained the highest quality. Any interruption of the integrity of low temperature in the cold chain resulted in varied quality deterioration. Therefore, processors and consumers should maintain washed eggs in a cold chain from postwashing until consumption to maintain the quality and safety of eggs.

\section{INTRODUCTION}

Eggs, an inexpensive and excellent protein source, are considered one of the most nutritious foods (Liu et al., 2016). Because contaminated eggs are a potential foodborne source of salmonellosis (Lublin \& Sela, 2008), after being collected from laying farms, eggs are frequently washed commercially. The process includes the eggs being wetted, washed, rinsed, sanitized, and dried to improve their microbial characteristics (Messens et al., 2011). Post washing procedures commonly include temporary storage, transportation, selling, and storage until consumption of the eggs. During storage, eggs undergo physicochemical changes, such as moisture loss, increasing of albumen $\mathrm{pH}$, and weakening of vitelline membranes (Samli et al., 2005). Wellknown variables, such as the Haugh unit $(\mathrm{HU})$, albumen $\mathrm{pH}$, and yolk $\mathrm{pH}$ are commonly measured to determine egg freshness (Liu et al., 2016).

Egg preservation mainly relies on storage temperature and time management (Samli et al., 2005; Liu et al., 2016). Numerous studies have evaluated the influences of storage temperature and duration on the quality of the eggs (Liu et al., 2016). Most published studies have presented measurements to argue that the higher the storage temperature is, the worse the egg quality will be, and the longer the storage duration is, the worse the egg quality will be (Keener et al., 2006). Lublin \& Sela (2008) evaluated the effect of temperature during storage on the viability of Salmonella in eggs and Gast \& Holt (2000) found that both subsequent penetration of Salmonella enteritidis into the shell and growth in the exposed eggs were accelerated by higher temperature and longer storage. Because Salmonella are capable of multiplying to great numbers in table eggs stored at ambient temperature, maintaining eggs at a low holding temperature has been recommended as an effective 
Influence of Cold Chain Integrity during Postwashing Processing and Storage on Chicken Egg Quality practice to control egg borne salmonellosis (Lublin \& Sela, 2008; Gross et al., 2015).

"Cold chain" refers to a succession of cold storage facilities along a supply chain, in which perishable foods, such as eggs, dairy, meat, poultry, and fish are kept in appropriate temperature ranges to slow down biological degradation so that safe and highquality foods can be delivered to consumers (Mercier et al., 2017). Temperature abuses in cold chain might result in compromised quality and safety of foods that eventually lead to the loss of consumer confidence (Ndraha et al., 2018). Various studies have assessed the quality and safety of agricultural products from harvest to retail display at several steps in cold chains (Stahl et al., 2015). Temperature control along the cold chain is critical to maintain the quality of refrigerated food products (Laguerre et al., 2013). The influences of temperature abuses in a cold chain have been frequently investigated (Derens et al., 2006; Koutsoumanis et al., 2010). Heap (2006) emphasized that cold chains should always be considered a complete process. Applying various predictive models, suggested that $4^{\circ} \mathrm{C}$ is a more inhibitory temperature than $8^{\circ} \mathrm{C}$ and $20^{\circ} \mathrm{C}$ for table eggs externally contaminated by $\mathrm{S}$. enterica serovar Enteritidis during a 28-day storage period. Therefore, keeping eggs at a constant $4^{\circ} \mathrm{C}$ throughout the storage period should be considered during risk assessment (Pasquali et al., 2016). Because an increase in temperature in a cold chain can lead to condensation forming on the eggshell, potentially increasing the risk of growth and penetration of microorganisms, including Salmonella spp. present on the surface of the eggshell, Messens et al. (2011) suggested that refrigerated eggs be kept at refrigeration temperature throughout the distribution chain.

According to the regulation Council of the European Union (2004), eggs "must be stored and transported until sale to the final consumer at a temperature, preferably constant, that is best suited to assure optimal conservation of their hygiene properties" (Gross et al., 2015). In Germany, commercialized shell eggs must be cooled at $5-8{ }^{\circ} \mathrm{C}$ from the eighteenth day after laying for transportation and throughout storage (Animal food hygiene regulation (Tier-LMHV), 2007). In the United States, shell eggs packed for consumers must be kept at a temperature not greater than $7.2^{\circ} \mathrm{C}$ after processing, during transportation, and throughout storage, and be labeled with a refrigeration request statement according to the regulations enforced by the Food Safety and Inspection Service (Messens et al., 2011).

To provide safe and high-quality washed eggs, attention must be paid to every aspect of the cold chain from production to consumption. When surveying egg purchase, storage, and preparation behaviors in selected Asian and European countries, Koppel et al. (2014) and Koppel et al. (2015) found that most participating consumers purchased eggs either from refrigerated environments or from room-temperature environments, but that most consumers stored their eggs in refrigerators after purchase. Cooling and consequently maintaining washed eggs under refrigeration has been recommended to retard the growth of pathogens, particularly Salmonella, in eggs (Messens et al., 2011). To the best of our knowledge, this is the first study that has emphasized and has systematically been designed to evaluate the influence of cold chain integrity on post washed egg quality. In the current study, the quality levels of the post washed eggs that were assigned to several groups according to their simulated storage combinations of post washing processes were evaluated during 4 weeks of storage at different temperatures.

\section{MATERIALS AND METHODS}

\section{Cold chain preparation and sampling}

A total of 400 freshly laid chicken eggs, obtained from a single flock were transported to a commercial washing plant (Taichung, Taiwan). After being washed, the eggs were delivered to our laboratory within 20 min and assigned to the eight groups presented in Table 1. The post washing processing in the current

Table 1 - Description of post-washing handling of eggs in cold chain.

\begin{tabular}{|c|c|c|c|}
\hline Step 1 & Step 2 & Step 3 & Code of treatment \\
\hline Post-washing temporary storage ( 1 day) & Transportation (8 h) & Selling and storage (0-4 week) & \\
\hline \multirow[t]{4}{*}{ Low temperature $\left(7^{\circ} \mathrm{C}\right)$} & Low temperature $\left(7^{\circ} \mathrm{C}\right)$ & Low temperature $\left(7^{\circ} \mathrm{C}\right)$ & LLL \\
\hline & & Room temperature $\left(25^{\circ} \mathrm{C}\right)$ & LLR \\
\hline & High temperature $\left(30^{\circ} \mathrm{C}\right)$ & Low temperature $\left(7^{\circ} \mathrm{C}\right)$ & LHL \\
\hline & & Room temperature $\left(25^{\circ} \mathrm{C}\right)$ & LHR \\
\hline \multirow[t]{4}{*}{ Room temperature $\left(25^{\circ} \mathrm{C}\right)$} & Low temperature $\left(7^{\circ} \mathrm{C}\right)$ & Low temperature $\left(7^{\circ} \mathrm{C}\right)$ & RLL \\
\hline & & Room temperature $\left(25^{\circ} \mathrm{C}\right)$ & RLR \\
\hline & High temperature $\left(30^{\circ} \mathrm{C}\right)$ & Low temperature $\left(7^{\circ} \mathrm{C}\right)$ & $\mathrm{RHL}$ \\
\hline & & Room temperature $\left(25^{\circ} \mathrm{C}\right)$ & RHR \\
\hline
\end{tabular}


Simsiri U, Rungruengpet W, Kaewkot C, Sun YM, Swiąder K, Wanangkarn A, Tan FJ
Influence of Cold Chain Integrity during Postwashing Processing and Storage on Chicken Egg Quality study consisted of three processing steps to simulate typical commercial egg handling in Taiwan. Briefly, after washing, the eggs were stored at $25^{\circ} \mathrm{C}$ or 7 ${ }^{\circ} \mathrm{C}$ for 1 day for step 1 (i.e., post washing temporary storage). Then, the eggs were stored at $7{ }^{\circ} \mathrm{C}$ or $30^{\circ} \mathrm{C}$ for $8 \mathrm{~h}$ for step 2 (i.e., transportation); finally, the eggs were stored at $7{ }^{\circ} \mathrm{C}$ or $25^{\circ} \mathrm{C}$ for 4 weeks for step 3 (i.e., selling and storage). All eggs were stored in an incubator (EYELA SLI-700, Rikakikai Co. Ltd., Tokyo, Japan) and refrigerator during processing and were analyzed every week.

\section{Egg quality determination}

Cumulative weight loss of eggs was determined according to the method of Liu et al. (2016). During storage, each egg was weighed. After weighing, a cumulative weight loss (\%) was calculated using the following formula: current weight - weight of week 0 . The eggs were then manually shelled and placed on the flat surface of an egg quality measurement stand (NFN-381, FHK Fujihira Industry Co. Ltd., Tokyo, Japan). The heights of thick albumen were determined using an egg quality gauge (FHK NFR3, Ozaki Manufacturing, Japan) to calculate the HU using the formula $100 \log (\mathrm{h}$ $-1.7 w 0.37+7.6)$, where $h$ and $w$ are the height of the albumen $(\mathrm{mm})$ and weight of the egg $(\mathrm{g})$, respectively. Yolk index (YI) was calculated according to the method of Liu et al. (2016) by measuring the width and height of the yolk by using the same micrometer, as follows: $\mathrm{YI}=$ (yolk height)/(yolk width). After pouring albumen through a 2-mm mesh nylon sieve, the volumes of filtrate (thin albumen) and residue (thick albumen) were recorded to calculate the albumen ratio by using the formula (volume of thick albumen) / (volume of thin albumen). The albumen moisture content was measured according to the method of Liu et al. (2016). The $\mathrm{pH}$ of homogenized albumen and yolk (BagMixre, InterScience, Saint-Nom-la-Brèteche, France; for 30 s) was measured using a pH meter (PHM210 Standard, Radiometer, Villeurbanne (edex, France).

\section{Microbiological analyses}

The changes of microorganisms on the eggshell surface and egg content during storage were determined according to the method of Cader et al. (2014). Each egg was aseptically placed in a sterile plastic bag containing $10 \mathrm{~mL}$ of $0.1 \%$ peptone solution and was softly hand-shaken for 1 min to release bacteria from the eggshell surface. After the eggshell had been sprayed with $75 \%$ ethanol, the egg was manually cracked. The yolk and albumen were homogenized using a stomacher (BagMixre,
InterScience, Saint-Nom-la-Brèteche, France) for 30 $\mathrm{sec}$, in a 1:10 dilution of $0.1 \%$ peptone water. Serial dilutions were made in $0.1 \%$ peptone water. For the total plate count (TPC), viable cells of eggshell and egg content (log CFU/mL) were enumerated on plate count agar by using the pour plate method, followed by incubation at $35^{\circ} \mathrm{C}$ for $48 \mathrm{~h}$. The presence or absence of Salmonella spp. in each egg was determined using the 3M Petrifilm Salmonella Express system according to the manufacturer's manual.

\section{Statistical analysis}

The means of the data were compared using oneway analysis of variance with a $5 \%$ level of significance. Means were separated using the Scheffé test. All statistical analyses were performed using Statistical Analysis System software.

\section{RESULTS AND DISCUSSION}

\section{Haugh units and other freshness para- meters}

Table 2 illustrates the changes in the HUs of the eggs during storage. In the current study, the eggs with $\mathrm{HU}$ values of $>72,71-60,59-31$, and $<31$ were classified into grades $A A, A, B$, and $C$, respectively, on the basis of the standards of the United States Department of Agriculture (USDA, 2000). At week 0, all treatments had HUs of approximately 64 to 70, and were classified as grade $A$ quality, without significant difference ( $p>0.05)$ between treatments. When considering the influence of step 1 (post washing temporary storage), it was found that the HUs of eggs stored at $7^{\circ} \mathrm{C}$ were higher than the corresponding eggs stored at $25^{\circ} \mathrm{C}$ during step 1 despite both having the same storage conditions for the other steps in the cold chain (i.e., $\boldsymbol{L L L}>\boldsymbol{R} L \mathrm{~L}, \boldsymbol{L L R}>\boldsymbol{R} \mathrm{LR}, \boldsymbol{L H L}>\boldsymbol{R} H \mathrm{~L}$, and $\boldsymbol{L H R}>\boldsymbol{R} H \mathrm{H})$. At week 0 , such numerical but not statistical $(p>0.05)$ differences were observed between the corresponding treatments; the differences became more obvious and significant $(p<0.05)$ thereafter until the end of the 4-week storage with some minor exceptions. When considering the influence of step 2 (transportation), the HUs of eggs stored at $7{ }^{\circ} \mathrm{C}$ were numerically but not statistically $(p>0.05)$ higher than the corresponding eggs stored at $30^{\circ} \mathrm{C}$ (i.e., $L L L \geq L \boldsymbol{H} L, L \boldsymbol{L} R \geq L \boldsymbol{H} R$, $R \boldsymbol{L} L$ $\geq R \boldsymbol{H} L$, and $R \boldsymbol{L} R \geq R \boldsymbol{H} R$ ) during storage. The small difference observed between the corresponding treatments was probably due to the short processing time (i.e., 8 h) of step 2 . When considering the influence of step 3 (selling and storage), the HUs of eggs stored at $7{ }^{\circ} \mathrm{C}$ at this step were higher than the corresponding 
Table 2 - Changes in Haugh units and USDA egg quality standards of eggs during storage.

\begin{tabular}{|c|c|c|c|c|c|}
\hline \multirow{2}{*}{ Treatments } & \multicolumn{5}{|c|}{ Storage time (week) } \\
\hline & 0 & 1 & 2 & 3 & 4 \\
\hline LLL & $\begin{array}{c}70.17 \pm 2.05^{\mathrm{Aa}} \\
A^{*}\end{array}$ & $\begin{array}{c}68.24 \pm 3.56 \text { Aab } \\
A\end{array}$ & $\begin{array}{c}65.44 \pm 3.48 \text { Aabc } \\
A\end{array}$ & $\begin{array}{c}62.78 \pm 5.32 \mathrm{Abc} \\
A\end{array}$ & $\begin{array}{c}60.69 \pm 1.22 \mathrm{Ac} \\
\mathrm{A}\end{array}$ \\
\hline LLR & $\begin{array}{c}69.59 \pm 5.02^{\mathrm{Aa}} \\
\mathrm{A}\end{array}$ & $\begin{array}{c}50.77 \pm 0.93^{\mathrm{Cab}} \\
\text { B }\end{array}$ & $\begin{array}{c}38.20 \pm 1.46^{\text {Dab }} \\
B\end{array}$ & $\begin{array}{c}37.68 \pm 2.93^{\mathrm{Db}} \\
B\end{array}$ & $N D^{* *}$ \\
\hline LHL & $\begin{array}{c}67.57 \pm 0.82^{\mathrm{Aa}} \\
\mathrm{A}\end{array}$ & $\begin{array}{c}66.49 \pm 1.86^{\mathrm{Aa}} \\
\mathrm{A}\end{array}$ & $\begin{array}{c}62.12 \pm 1.86^{\mathrm{Bb}} \\
\mathrm{A}\end{array}$ & $\begin{array}{c}60.47 \pm 3.45^{\mathrm{ABb}} \\
A\end{array}$ & $\begin{array}{c}54.66 \pm 1.19 \mathrm{BC} \\
B\end{array}$ \\
\hline LHR & $\begin{array}{c}66.83 \pm 0.72^{\mathrm{Aa}} \\
\mathrm{A}\end{array}$ & $\begin{array}{c}48.12 \pm 0.68^{\mathrm{CDb}} \\
\mathrm{B}\end{array}$ & $\begin{array}{c}36.14 \pm 1.56^{\mathrm{DEC}} \\
B\end{array}$ & $\begin{array}{c}33.60 \pm 4.18^{\mathrm{DEC}} \\
\mathrm{B}\end{array}$ & ND \\
\hline RLL & $\begin{array}{c}65.81 \pm 1.32 \mathrm{Aa} \\
\mathrm{A}\end{array}$ & $\begin{array}{c}64.45 \pm 1.144^{\mathrm{ABab}} \\
\mathrm{A}\end{array}$ & $\begin{array}{c}59.54 \pm 2.57 \mathrm{BCbC} \\
B\end{array}$ & $\begin{array}{c}55.20 \pm 5.47^{B C d C} \\
B\end{array}$ & $\begin{array}{c}52.14 \pm 3.36^{\mathrm{Bd}} \\
B\end{array}$ \\
\hline RLR & $\begin{array}{c}64.51 \pm 1.14^{\mathrm{Aa}} \\
\mathrm{A}\end{array}$ & $\begin{array}{c}46.17 \pm 1.71^{\mathrm{DEb}} \\
\mathrm{B}\end{array}$ & $\begin{array}{c}34.84 \pm 2.09 \mathrm{Ec} \\
B\end{array}$ & $\begin{array}{c}27.67 \pm 3.44^{\mathrm{EFd}} \\
C\end{array}$ & ND \\
\hline RHL & $\begin{array}{c}64.65 \pm 0.86^{\mathrm{Aa}} \\
\mathrm{A}\end{array}$ & $\begin{array}{c}61.79 \pm 1.30^{\mathrm{Ba}} \\
\mathrm{A}\end{array}$ & $\begin{array}{c}56.60 \pm 1.08 \mathrm{cb} \\
B\end{array}$ & $\begin{array}{c}54.03 \pm 3.58 \mathrm{cbc} \\
B\end{array}$ & $\begin{array}{c}50.65 \pm 4.74^{B C} \\
B\end{array}$ \\
\hline RHR & $\begin{array}{c}64.01 \pm 1.42 \mathrm{Aa} \\
\mathrm{A}\end{array}$ & $\begin{array}{c}42.29 \pm 5.89 \mathrm{~Eb} \\
B\end{array}$ & $\begin{array}{c}30.43 \pm 1.52^{\mathrm{Fc}} \\
\mathrm{C}\end{array}$ & $\begin{array}{c}26.70 \pm 2.67^{\mathrm{Fc}} \\
\mathrm{C}\end{array}$ & ND \\
\hline
\end{tabular}

Abbreviations are the same illustrated in Table 1.

*USDA egg quality standard: grade $A A, A, B$, and $C=H U$ s of $>72,71-60,59-31$, and $<31$, respectively.

**ND: not determined due to weakening and broken vitelline membrane.

eggs stored at $25^{\circ} \mathrm{C}$ (i.e., $\mathrm{LL} \boldsymbol{L}>\mathrm{LL} \boldsymbol{R}, \mathrm{LH} \boldsymbol{L}>\mathrm{LH} \boldsymbol{R}, \mathrm{RL} \boldsymbol{L}$ $>\mathrm{RL} \boldsymbol{R}$, and $\mathrm{RH} \boldsymbol{L}>\mathrm{RH} \boldsymbol{R})$. Numerical but not statistical differences were observed between the corresponding treatments at week 0 ( $p>0.05)$, and these differences became significant $(p<0.05)$ thereafter until the end of storage. At week 4, LLL eggs remained grade A quality, whereas $L H L, R L L$, and $R H L$ eggs changed to grade $B$. The quality of the other 4 groups (LLR, LHR, RLR, and $R H R$ ), subjected to storage at $25^{\circ} \mathrm{C}$ during step 3 for 4 weeks, deteriorated substantially, as evidenced by weakened or broken vitelline membranes. Thus, the researchers were unable to determine the HUs and other quality parameters. It is notable that only LLL eggs, which were kept at a low temperature of $7{ }^{\circ} \mathrm{C}$ during the whole three post washing steps in the cold chain, remained grade $A$ quality until the end of the 4-week storage period, demonstrating the importance of the integrity of the cold chain to maintain the quality of washed eggs. Similar changing patterns in HUs due to the influence of various post washing processes in the cold chain were also observed in the thick albumen ratio (Figure $1(\mathrm{a})$ ) and $\mathrm{YI}$ (Figure 1(b)) of eggs. The results clearly demonstrated that storage temperature and duration have considerable effects on egg quality.

During extended storage, thick albumen, the highly viscous part of egg albumen adjacent to the yolk, progressively loses its gelatinous structure, eventually causing the thinning of the thick albumen and decreases in $\mathrm{HU}$ values (Liu et al., 2016). Moreover, migration of water from the albumen through the weaker vitelline membrane causes yolk flattening and decreased YI (Liu et al., 2016). At lower temperatures, eggs have been reported to maintain superior characteristics such as $\mathrm{HU}$ and albumen height, while reducing weight loss, and albumen pH (Samli et al., 2005). The yolk height for eggs stored at $23^{\circ} \mathrm{C}$ was approximately $10 \%$ lower than that for eggs stored at $5^{\circ} \mathrm{C}$, whereas only a slight difference was observed in yolk heights of eggs stored for different lengths of time; Keener et al. (2006) have suggested that the vitelline membrane was highly sensitive to temperature changes during storage. Based on the results demonstrating cooling would extend the time period before the yolk vitelline breaks down, Gross et al. (2015) supported the requirement of German legislation to cool eggs from the $18^{\text {th }}$ day onwards after laying. Liu et al. (2016) observed that the $\mathrm{HU}$ of washed eggs stored at $7^{\circ} \mathrm{C}$ decreased slightly after storage for 4 weeks, whereas the HU of the eggs stored at $25^{\circ} \mathrm{C}$ decreased sharply after the eggs had been stored more than 2 weeks. Increases in the albumen $\mathrm{pH}$ and yolk $\mathrm{pH}$ (Figure 1(c), Figure $1(d)$ ) of the eggs during storage were probably caused by changes in the carbonic acid-bicarbonate buffer system in the albumen; these changes were probably triggered by the release of carbon dioxide (Samli et al., 2005; Liu et al., 2016).

\section{Weight loss}

At week 1 , weight loss ranged from $0.27 \%-0.65 \%$. The LLL and RHR groups had the lowest and highest weight loss values, respectively (Figure 2(a)). Weight loss values of all treatments increased at various rates during extended storage. High processing temperatures for certain treatments in steps 1 and 2 resulted in their 
Simsiri U, Rungruengpet W, Kaewkot C, Sun YM, Swiąder K, Wanangkarn A, Tan FJ (a)

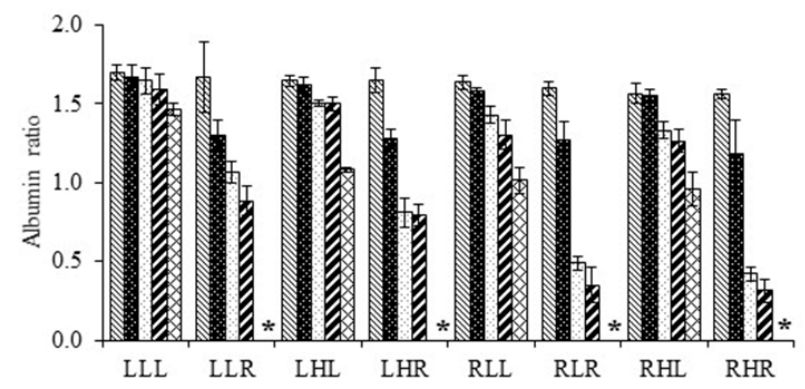

(c)

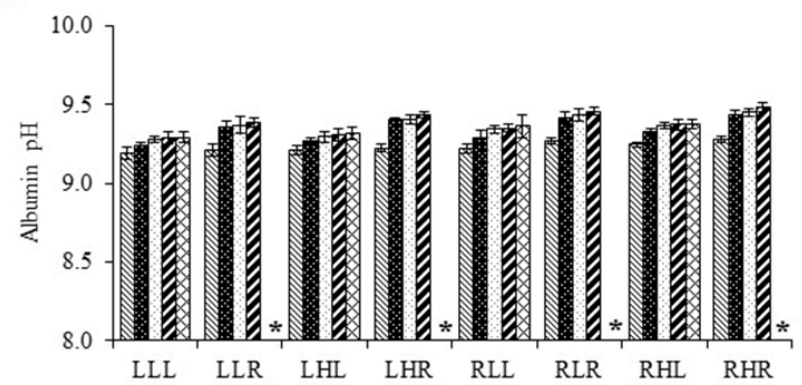

(b)

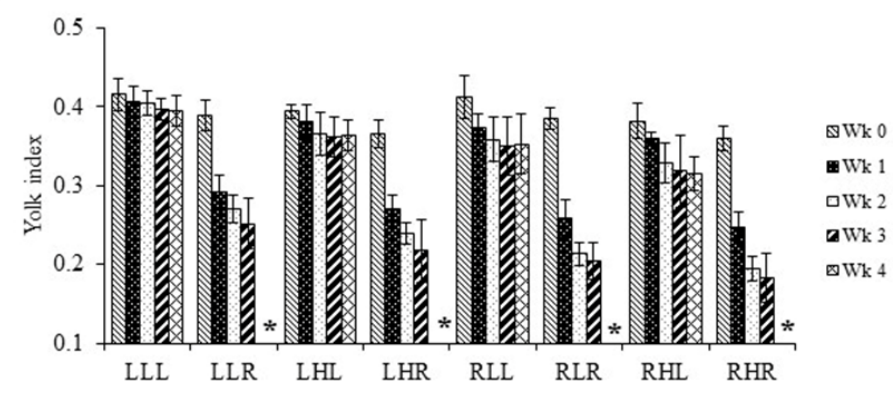

(d)

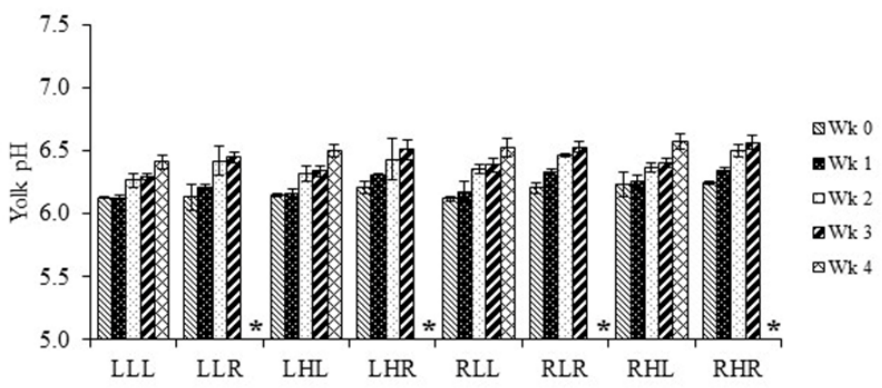

Figure 1 - Changes in (a) albumen ratio, (b) yolk index, (c) albumen $\mathrm{pH}$, and (d) yolk pH of eggs during storage.

Abbreviations are the same illustrated in Table 1.

*ND: not determined due to weakening and broken vitelline membrane.

high weight losses. Regarding the influence of step 3, refrigerated eggs ( $L L \boldsymbol{L}, L H \boldsymbol{L}, R L \boldsymbol{L}$, and $R H \boldsymbol{L}$ ) suffered less weight loss than eggs stored at $25^{\circ} \mathrm{C}$ ( LLR, LHR, $\mathrm{RL} \boldsymbol{R}$, and $\mathrm{RH} \boldsymbol{R}$ ) did. At the end of the 4-week storage period, cumulative weight losses were $0.82-1.06 \%$ for the refrigerated eggs in step 3, whereas significantly

(a)

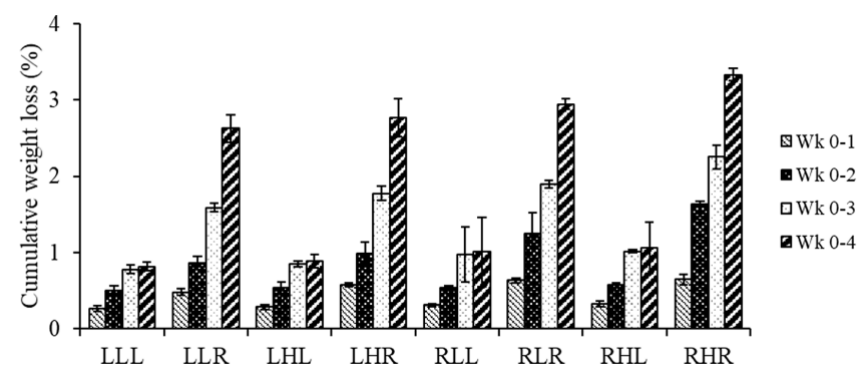

(b)

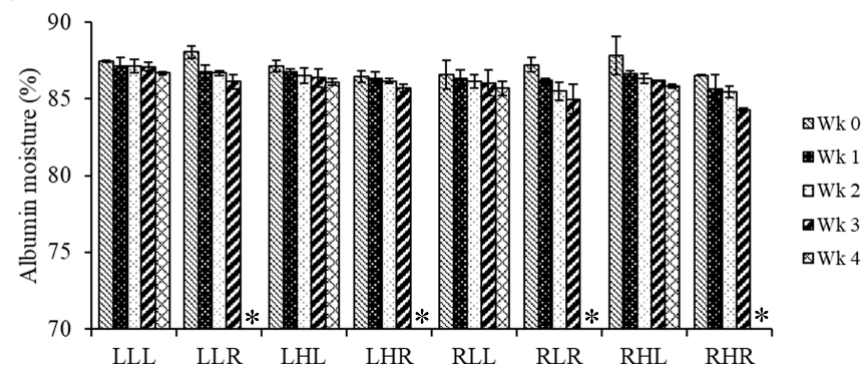

Figure $\mathbf{2}$ - Changes in (a) cumulative weight loss and (b) albumen moisture contents of eggs during storage.

Abbreviations are the same illustrated in Table 1.

*ND: not determined due to weakening and broken vitelline membrane. higher losses of 2.63-3.33\% were observed for the eggs stored at $25^{\circ} \mathrm{C}$ in step 3. Any interruption of low temperature maintenance during the cold chain could result in higher weight losses of varying degrees. High temperatures and long storage times led to decreases of albumen moisture contents (Figure 2(b)) (Jones et al., 2018); these eventually led to losses of water and carbon dioxide through the eggshells during storage. High temperatures and long storage times apparently caused steep weight losses. Regarding observations of scanning electron microscopic images and cuticle staining, Liu et al. (2016) confirmed that cuticle coverage can be decreased by extended storage, and reported that cuticle deterioration of eggs stored at 25 ${ }^{\circ} \mathrm{C}$ was more obvious than that of eggs stored at $7{ }^{\circ} \mathrm{C}$.

\section{Microbial quality}

Figure 3 shows the changes in the TPCs of eggshells during storage. Regarding the effects of step 1 for groups that had had the same storage conditions for other steps in the cold chain (i.e., $\boldsymbol{L L L}<\boldsymbol{R} L \mathrm{~L}, \boldsymbol{L L R}<$ $\boldsymbol{R} \mathrm{LR}, \boldsymbol{L H L}<\boldsymbol{R} H \mathrm{~L}$, and $\boldsymbol{L H R}<\boldsymbol{R} H \mathrm{H}$ ), the eggshell TPCS of the eggs stored at $7{ }^{\circ} \mathrm{C}$ were significantly $(p<$ 0.05) lower than those of the eggs stored at $25^{\circ} \mathrm{C}$. Regarding the effects of step 2 (transportation) for comparable groups, the eggshell TPCs of the eggs stored at $7{ }^{\circ} \mathrm{C}$ were close to or slightly lower than that of the corresponding eggs stored at $30^{\circ} \mathrm{C}$ during this step (i.e., $L \boldsymbol{L} L \leq L \boldsymbol{H} L, L \boldsymbol{L} R \leq L \boldsymbol{H} R, R \boldsymbol{L} L \leq R \boldsymbol{H} L$, and $R \boldsymbol{L} R$ 
Simsiri U, Rungruengpet W, Kaewkot C, Sun YM, Swiąder K, Wanangkarn A, Tan FJ
Influence of Cold Chain Integrity during Postwashing Processing and Storage on Chicken Egg Quality $\leq \mathrm{R} \boldsymbol{H R}$ ) during storage. The small difference between the corresponding treatments was probably because of the short processing time (i.e., 8 h) of step 2 . Regarding the effects of step 3 (selling and storage) on comparable groups, at week 0 the eggshell TPCs of the eggs stored at $7^{\circ} \mathrm{C}$ during step 3 were significantly lower than those of the corresponding eggs stored at $25{ }^{\circ} \mathrm{C}$ (i.e., $\mathrm{LL} \boldsymbol{L}<\mathrm{LL} \boldsymbol{R}, \mathrm{LH} \boldsymbol{L}<\mathrm{LH} \boldsymbol{R}, \mathrm{RL} \boldsymbol{L}<\mathrm{RL} \boldsymbol{R}$, and $\mathrm{RH} \boldsymbol{L}$ $<\mathrm{RH} \boldsymbol{R})$. Such differences between the corresponding treatments became more obvious after storage for one or more weeks. Furthermore, the eggshell TPCs of the eggs stored at refrigerated temperatures ( $L L L, L H \boldsymbol{L}, R L \boldsymbol{L}$, and $\mathrm{RH} \boldsymbol{L}$ ) started to decrease during storage, whereas the eggshell TPCs of the eggs stored at ambient temperature ( $L L \boldsymbol{R}, L H \boldsymbol{R}, R L \boldsymbol{R}$, and $R H \boldsymbol{R}$ ) increased. Such changing microbial patterns during storage due to the effect of storage temperature were in agreement with a study done by Aygun \& Sert (2013). It is notable that $\mathrm{LLL}$, which was maintained at a temperature of $7{ }^{\circ} \mathrm{C}$ during all three post washing steps in the cold chain, had the lowest TPC until the end of the 4-week storage period, illustrating the importance of integrity of the cold chain to minimize the microbial content of washed eggs. No Salmonella and total aerobic bacteria were detected in the egg contents for all treatments during the 4-week storage period in the current study.

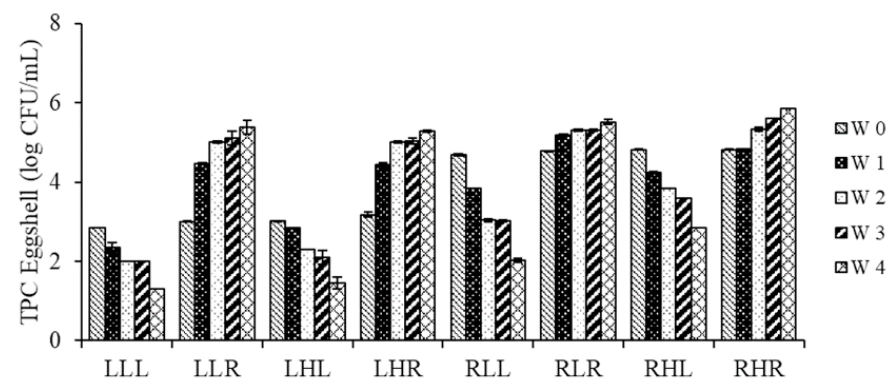

Figure 3 - Changes in total plate counts (TPC) of eggshells during storage. Abbreviations are the same illustrated in Table 1

Significantly lower microbial counts including total aerobic bacteria and Salmonella spp. were observed when eggs were stored at $5{ }^{\circ} \mathrm{C}$ compared with 22 ${ }^{\circ} \mathrm{C}$ during 42 days of storage (Aygun \& Sert, 2013). Cooling of table eggs during storage is considered as an effective manner to prevent the growth of pathogens including Salmonella spp. (EFSA, 2005; Gross et al., 2015). Lublin \& Sela (2008) found that Salmonella enterica serovar Virchow and Enteritidis were able to multiply to large numbers in table eggs that had been stored at $25^{\circ} \mathrm{C}$. During extended storage at ambient temperature, liquefying of egg albumen probably would result in a movement of yolk closer to the eggshell, potentially increasing the risk of bacterial penetration into the yolk (EFSA, 2014;
Baron et al., 2016). Gast \& Holt (2000) suggested the necessity of rapidly achieving microbial growthrestricting refrigeration temperatures of the eggs. FDA regulations, which limit storage temperatures of table eggs to less than $7.2^{\circ} \mathrm{C}$, should be sufficient to inhibit potential growth but apparently do not limit potential penetration of pathogens including Salmonella spp. through eggshell barriers. Therefore, Lublin \& Sela (2008) recommend that the prompt refrigeration of eggs should be followed to secure consumers' health. Any possible recontamination during processing, particularly after washing until consumption, should be avoided (Gole et al., 2014). Cold chain disruption, which might cause condensation on the eggshell, thus increasing potential penetration into eggs, should also be prevented (EFSA, 2009). Continuous temperature tracking and monitoring along the supply chain, particularly utilizing some novel techniques, are critical for cold chain management (Bruckner et al., 2012; Ndraha et al., 2018).

\section{CONCLUSION}

Cold chain logistics, which is the temperaturecontrolled transport and storage of perishable goods between initial production and final consumption, has a considerable influence on the quality and safety of perishable foods. Since table eggs are considered a potential source of Salmonella, refrigeration has been suggested as a possible method to reduce the incidence of egg borne salmonellosis. The current study clearly demonstrated that washed eggs maintained, in simulated post washing processing at $7{ }^{\circ} \mathrm{C}$, for the entire cold chain, superior characteristics during a 4-week storage period. By contrast, any interruption of the integrity of low temperatures in the cold chain resulted in varying degrees of deterioration. Nutritious and perishable eggs should be processed and stored in a cold chain from post washing until consumption to maintain quality and safety.

\section{ACKNOWLEDGMENTS}

The assistant from Miss Jutamas Nakwikrai was grateful.

\section{FUNDING}

This work was financially supported by the Council of Agriculture, Taiwan (108AS-26.1.1-LI-U2). The assistant from Mr. Yung-Hsun Hung and Miss Jutamas Nakwikrai was grateful. 
Influence of Cold Chain Integrity during Postwashing Processing and Storage on Chicken Egg Quality

\section{REFERENCES}

Animal Food Hygiene Regulation (Tier-LMHV). Regulation of the demands on hygiene for production, manipulation and marketing of distinct foodstuffs of animal origin. Federal Law Gazette (BGBI); 2007.

Aygun A, Sert D. Effects of vacuum packing on eggshell microbial activity and egg quality in table eggs under different storage temperatures. Journal of the Science of Food and Agriculture 2013;93(7):1626-1632.

Baron F, Nau F, Guérin-Dubiard C, Bonnassie S, Gautier M, Andrews SC, et al. Egg white versus Salmonella Enteritidis! A harsh medium meets a resilient pathogen. Food Microbiology 2016;53:82-93.

Bruckner S, Albrecht A, Petersen B, Kreyenschmidt J. Influence of cold chain interruptions on the shelf life of fresh pork and poultry. International Journal of Food Science and Technology 2012;47:1639-1646.

Cader S, Goburdhun D, Neetoo H. Assessment of the microbial safety and quality of eggs from small and large-scale hen breeders. Journal of World's Poultry Research 2014;4(4):75-81.

Council of European Union. Council Regulation (EC) No 853/2004. 2004. Available from: http://data.europa.eu/eli/reg/2004/853/oj

Derens E, Palagos B, Guilpart J. The cold chain of chilled products under supervision in France. Proceedings of the 13th World Congress of Food Science \& Technology; 2006; Les Ulis, France: EDP Sciences; 2006. p.1503-1510.

EFSA. Scientific Opinion - Special measures to reduce the risk for consumers through Salmonella in table eggs - e.g. cooling of table eggs - Scientific Opinion of the Panel on Biological Hazards. The EFSA Journal 2009;957:1-29.

EFSA. Opinion of the scientific panel on biological hazards (BIOHAZ) related to the microbiological risks on washing of table eggs. The EFSA Journal 2005;269:1-39.

EFSA. Scientific Opinion - Scientific opinion on the public health risks of table eggs due to deterioration and development of pathogens. EFSA Panel on Biological Hazards (BIOHAZ). The EFSA Journal 2014;12(7):3782.

Gast RK, Holt PS. Influence of the level and location of contamination on the multiplication of Salmonella enteritidis at different storage temperatures in experimentally inoculated eggs. Poultry Science 2000;79(4):559-563

Gole VC, Roberts JR, Sexton M, May D, Kiermeier A, Chousalkar KK. Effect of egg washing and correlation between cuticle and egg penetration by various Salmonella strains. International Journal of Food Microbiology 2014;182:18-25

Gross S, Johne A, Adolphs J, Schlichting D, Stingl K, Müller-Graf C, et al. Salmonella in table eggs from farm to retail - When is cooling required? Food Control 2015;47:254-263.

Heap RD. Cold chain performance issues now and in the future. Innovative equipment and systems for comfort and food preservation, meeting of IIR commissions B2, E1 with C2, D1, D2, Auckland, New Zealand. Paris: International Institute of Refrigeration; 2006.

Jones DR, Ward GE, Regmi P, Karcher DM. Impact of egg handling and conditions during extended storage on egg quality. Poultry Science 2018;97(2):716-723.
Keener KM, McAvoy KC, Foegeding JB, Curtis PA, Anderson KE, Osborne $J A$. Effect of testing temperature on internal egg quality measurements. Poultry Science 2006;85(3):550-555.

Koppel K, Timberg L, Shalimov R, Vázquez-Araújo L, Carbonell-Barracchina AA, Di Donfrancesco B, Chambers IVE. Purchase, storage, and preparation of eggs and poultry in selected European countries. A preliminary study. British Food Journal 2015;117(2):749-765.

Koppel K, Suwonsichon S, Chitra U, Lee J, Chambers IV. Eggs and poultry purchase, storage, and preparation practices of consumers in selected Asian countries. Foods 2014;3(1):110-127.

Koutsoumanis K, Pavlis A, Nychas GJE, Xanthiakos K. Probabilistic model for Listeria monocytogenes growth during distribution, retail storage, and domestic storage of pasteurized milk. Applied and Environmental Microbiology 2010;76(7):2181-2191.

Laguerre O, Hoang HM, Flick D. Experimental investigation and modelling in the food cold chain: Thermal and quality evolution. Trends in Food Science \& Technology 2013;29(2):87-97.

Liu YC, Chen TH, Wu YC, Lee YC, Tan FJ. Effects of egg washing and storage temperature on the quality of eggshell cuticle and eggs. Food Chemistry 2016;211:687-693.

Lublin A, Sela S. The impact of temperature during the storage of table eggs on the viability of Salmonella enterica serovars Enteritidis and Virchow in the eggs. Poultry Science 2008;87(11):2208-2214.

Mercier S, Villeneuve S, Mondor M, Uysal I. Time-Temperature management along the food cold chain: A review of recent developments. Comprehensive Reviews in Food Science and Food Safety 2017;16(4):647-667.

Messens W, Gittins J, Leleu S, Sparks N. Egg decontamination by washing In: Immerseel FV, Nys Y, Bain M, editors. Improving the safety and quality of eggs and egg products. Egg safety and nutritional quality. Cambridge: Woodhead Publishing Limited; 2011. v.2. p.163-180.

Ndraha N, Hsiao HI, Vlajic J, Yang MF, Lin HTV. Time-temperature abuse in the food cold chain: Review of issues, challenges, and recommendations. Food Control 2018;89:12-21.

Pasquali F, Klein G, Reich F, Manfreda G, Valero A. Modelling survival behaviour of Salmonella enterica ser. Enteritidis, Typhimurium and Tennessee on table eggs during storage at different temperatures. Food Control 2016:59:314-319.

Samli HE, Agma A, Senkoylu N. Effects of storage time and temperature on egg quality in old laying hens. Journal of Applied Poultry Research 2005;14(3):548-553.

Stahl V, Ndoye FT, Jabri MEl, Page JFLe, Hezard B, Lintz A, et al. Safety and quality assessment of ready-to-eat pork products in the cold chain. Journal of Food Engineering 2015;148:43-52.

USDA. Egg Grading Manual. United States Department of Agriculture; 2000. Available from: https://www.ams.usda.gov/sites/default/files/ media/Egg\%20Grading\%20Manual.pdf 
